Original article

Section: Food Quality and Functionality

\title{
Proximate Composition, Mineral Profile and Trypsin-Inhibitory Activity of West African Leafy Vegetables: Influence of Urea Micro-Dosing and Harvest Time
}

\author{
Modoukpè Imayath Djibril Moussa ${ }^{1 *}$, Adeola Monisola Alashi ${ }^{2}$, Carole Nadia Adjouavi \\ Sossa-Vihotogbé3, Pierre Bienvenu Irénikatché Akponikpè $e^{4}$, Mohamed Nasser Baco ${ }^{5}$, \\ André Jonas Djènontin ${ }^{4}$, Rotimi Emmanuel Aluko², Noël Houédougbé Akissoé ${ }^{1}$ \\ ${ }^{\prime}$ Ecole de Nutrition, des Sciences et Technologies Alimentaires, Faculté des Sciences Agronomiques, \\ Université d'Abomey-Calavi, 03 BP 2819 Jéricho, Cotonou, République du Bénin \\ ${ }^{2}$ Department of Food and Human Nutritional Sciences, Faculty of Agricultural and Food Sciences, \\ University of Manitoba, Winnipeg, Manitoba, Canada R3T 2N2 \\ ${ }^{3}$ Département de Nutrition et Sciences Agro-Alimentaires, Faculté d'Agronomie, \\ Université de Parakou, République du Bénin \\ ${ }^{4}$ Laboratoire d'Hydraulique et de Modélisation Environnementale, Faculté d'Agronomie, \\ Université de Parakou, 03 BP 351, Parakou, République du Bénin \\ ${ }^{5}$ Laboratoire Société-Environnement, Faculté d'Agronomie, \\ Université de Parakou, BP 27, Parakou, République du Bénin
}

Key words: green leafy vegetables, harvest time, mineral composition, urea micro-dosing, trypsin inhibition

In order to ensure the nutritional quality of leafy vegetables produced under intensive cultivation systems, the proximate composition, mineral profile, and trypsin-inhibitory activity of three priority West African vegetable species (Amaranthus cruentus, Ocimum gratissimum, and Solanum macrocarpon) produced with urea micro-doses $(20,40$, and $60 \mathrm{~kg} / \mathrm{ha}$ ) were compared with control leaves raised without urea. Plants were harvested three consecutive times to determine effects on nutrient and trypsin-inhibitory activity. Proximate and mineral compositions were mainly species-dependent $(\mathrm{p}<0.05)$ though the $60 \mathrm{~kg} / \mathrm{ha}$ urea dose produced the significantly $(\mathrm{p}<0.05)$ highest moisture content in leaves. Calcium, copper, iron, and zinc contents were significantly $(\mathrm{p}<0.05)$ influenced by harvest time and its interaction with vegetable species. Furthermore, trypsin inhibition was significantly $(\mathrm{p}<0.05)$ higher for the second and third leaf harvests, which suggests that initial wounding from the first harvest enhanced synthesis of the inhibitor protein molecules.

\section{INTRODUCTION}

Plant foods play a key role in the maintenance of human life as they supply the needed nutritional elements that boost the immune system [Fonge et al., 2016; Das et al., 2017]. Vegetables are food resources that are considered as healthy foods worldwide [Souza et al., 2016; Das et al., 2017]. Among all vegetables, green leafy vegetables are available all year round, at relatively low cost, and are widely used as basic ingredients in traditional dishes and nutrition therapy [Fonge et al., 2016; Souza et al., 2016; Das et al., 2017]. In the Republic of Benin, a biodiversity inventory revealed 187 plant species used as indigenous leafy vegetables with Amaranthus cruentus (Amaranthaceae), Ocimum gratissimum (Lamiaceae), and Solanum macrocarpon (Solanaceae) being among the priority species [Dansi et al., 2008]. These species are essential

\footnotetext{
*Corresponding Author: E-mail: dimayath@gmail.com (M.I. Djibril Moussa)
}

in West African diets, because they are used in the preparation of sauces [Dansi et al., 2008; Vodouhè et al., 2012]. They are also rich in fibers, minerals, vitamins, and polyphenols, which are involved in the growth and maintenance of good health for all age groups [Nana et al., 2012; Adewale et al., 2014; Akinwunmi \& Omotayo, 2016]. The extracts obtained from these leafy vegetables have antioxidant and enzyme inhibitory activities that provide evidence for sustaining their use in traditional medicine to prevent and manage several human ailments [Nana et al., 2012; Adewale et al., 2014; Djibril Moussa et al., 2019a, b].

However, these leafy vegetables contain anti-nutrients such as protease inhibitors, which may have a negative impact on human health, by reducing protein digestibility and limiting the availability of essential amino acids [Patel \& Zaveri, 2015]. Thus, protease inhibitors can limit the caloric value of diets, which could be useful in disease conditions where excessive catabolic activity (e.g., pancreatitis) is undesirable [Jedinak et al., 2010]. Smaller quantities 
of trypsin inhibitors induced satiety by promoting the secretion of cholecystokinin, a satietogenic hormone associated with limited food, energy, and weight intakes [Carvalho et al., 2016]. Hence, consumption of leafy vegetable extracts having trypsin-inhibitory activities could be beneficial for the management of metabolic abnormalities resulting from high food and energy intakes. Moreover, anti-viral effects of trypsin inhibitors [Shahwar et al., 2012] could extend their health benefits, especially in rural areas where diarrhea is a common occurrence. Otherwise, trypsin inhibitors are proteinaceous in nature, which means that they are heat sensitive and can be partially or completely denatured and inactivated at elevated temperatures $\left(>60^{\circ} \mathrm{C}\right)$ [Allen et al., 2012; Pesoti et al., 2015].

The nutritional profile of leafy vegetables is affected by soil fertility [Fonge et al., 2016; Souza et al., 2016; Das et al., 2017], while efficient use of fertilizers (mineral and/ or organic) is of great interest because of consumer demand for healthier food sources [Tovihoudji et al., 2017; Likpètè et al., 2019]. A recent farming system known as fertilizer micro-dosing technology involves the application of small quantities of mineral fertilizer at an optimized time, depth, and distance to the target plant [Tovihoudji et al., 2017; Likpètè et al., 2019]. This technology gave promising prospects in terms of crops productivity although the combined application of mineral and organic fertilizers was recommended for its sustainability [Tovihoudji et al., 2017; Likpètè et al., 2019]. However, the effect of fertilizer micro-dosing on the nutritional properties of farming products, including leafy vegetables is far from being fully understood. Moreover, leaves maturity stage at harvest is an important factor that could influence their nutrient contents since plants' development stage affected nutrients uptake by plants [Sossa-Vihotogbé et al., 2013; Bvenura \& Afolayan, 2014a, b]. Therefore, this study was undertaken to assess proximate composition, mineral profile, and trypsin-inhibitory activity of $A$. cruentus, $O$. gratissimum, and $S$. macrocarpon leaves produced with urea micro-doses and harvested at different times.

\section{MATERIALS AND METHODS}

\section{Materials}

Plants (A. cruentus, O. gratissimum, and S. macrocarpon) were cultivated between January and June 2016 in an experimental farm at the Northern Center of National Agricultural Research Institute ("INRAB") in Republic of Benin (9 57 ' $\mathrm{N}, 2^{\circ} 43^{\prime} \mathrm{E}$ and $358 \mathrm{~m}$ a.s.1.; Ina village, Bembereke district). Seeds were bought from "INRAB" and grown in nurseries for four (A. cruentus) or six (O. gratissimum and S. macrocarpon) weeks. The experimental design was a randomized complete block, in four replicates for each vegetable species, with three rates of urea $(20,40$, and $60 \mathrm{~kg} / \mathrm{ha})$ applied immediately after transplanting through micro-dosing technology [Likpètè et al., 2019] while the control plots contained no urea $(0 \mathrm{~kg} / \mathrm{ha})$. Cattle manure $(5 \mathrm{t} / \mathrm{ha})$ was applied a week before transplantation to all the experimental plot units $(6 \mathrm{~m} \times 1 \mathrm{~m})$ as base fertilizer. Harvests were done, on the same plants by cutting the main stems at a height of $10 \mathrm{~cm}$ from soil level, excluding those of the border lines, at 4-6-8, 6-10-14, and 8-12-16 weeks after transplanting for $A$. cruentus, $S$. macrocarpon, and $O$. gratissimum, respectively. These harvest times correspond to late vegetative stage (before flower initiation) for each species. For the purpose of this study, samples of $2.5 \mathrm{~kg}$ of fresh leaves with stems were harvested from each experimental plot for each vegetable species at each harvest, then edible leaves were washed and oven-dried at $60^{\circ} \mathrm{C}$ using a Memmert UN450 drier (Memmert GmbH + Co. KG, Schwabach, Germany), for a minimum of $24 \mathrm{~h}$ or until a constant weight was achieved. Dried leaves were ground using a Cuisinart Grinder (Model DCG-12 BCC, Cuisinart, ON, Canada) and leaf powder was stored at $-20^{\circ} \mathrm{C}$.

\section{Proximate composition analysis}

Proximate analysis was carried out in duplicate using standard methods [AOAC, 2005; AOCS, 2009]. Moisture was determined by oven-drying (Heraeus T 5042 EK oven, Heraeus, Hanau, Germany) of fresh leaves at $105^{\circ} \mathrm{C}$ for $24 \mathrm{~h}$ [AOAC, 2005; method 930.15]. Protein content was determined as total nitrogen $(\times 6.25)$ using Kjeldahl method after $\mathrm{H}_{2} \mathrm{SO}_{4}(95 \%)$ digestion using Kjeldahl pastilles as a catalyst followed by distillation into $4 \%(w / v) \mathrm{H}_{3} \mathrm{BO}_{3}$ and titration with $0.1 \mathrm{M} \mathrm{HCl}$ [AOAC, 2005; method 990.03]. Crude fat content was determined after petroleum ether extraction in an Ankom XT10 extraction system (ANKOM Technology, NY, USA) [AOCS, 2009; method Am 5-04]. Crude fiber content was estimated after digestion with $\mathrm{H}_{2} \mathrm{SO}_{4}(1.25 \%$, $v / v)$ and $\mathrm{NaOH}(0.3 \mathrm{M})$, using an Ankom 220 fibre analyzer [AOCS, 2009 method Ba6a-05]. Ash content was determined by the incineration method in a muffle furnace (Vulcan A-550, Dentsply Ceramco Inc, York, PA, USA) at $550^{\circ} \mathrm{C}$ overnight for $6 \mathrm{~h}$ [AOAC, 2005; method 923.03]. Except for moisture content, proximate composition was expressed on dry weight basis (dwb).

\section{Mineral profile analysis}

Mineral profile (dwb) was determined in duplicate by digesting white ashes in a mixture of $\mathrm{HNO}_{3}$ and $\mathrm{HClO}_{4}$ (4:1) for $24 \mathrm{~h}$ [AOAC, 2005; method 968.08D]. The supernatant was filtered using Whatman No. 42 filter paper and the filtrate was analyzed by atomic absorption spectroscopy (PerkinElmer AAnalyst 200, PerkinElmer, MA, USA) to assess calcium, copper, iron, magnesium, manganese, potassium, sodium, and zinc contents. Phosphorus content was determined by colorimetric method at $680 \mathrm{~nm}$ using a UV mini 1240 spectrophotometer (Shimadzu Corp., Kyoto, Japan) [AOAC, 2005; method 968.08D]. The nutritional interrelationships between mineral levels were evaluated by calculating the following content ratios: calcium/magnesium, calcium/ phosphorus, calcium/potassium, iron/copper, sodium/magnesium, sodium/potassium, and zinc/copper [Watts, 2010].

\section{Trypsin inhibition assay}

Trypsin-inhibitory activity was assessed (in triplicate) by Patel \& Zaveri [2015] method with slight modifications using aqueous extract of the leaf powder [Djibril Moussa et al., 2019b]. Leaf powder (10 g) was transferred into double de- 
ionized water $(200 \mathrm{~mL})$ and the mixture was stirred for $2 \mathrm{~h}$ at $60^{\circ} \mathrm{C}$ before centrifuging for $30 \mathrm{~min}\left(5000 \times \mathrm{g}\right.$ at $\left.4^{\circ} \mathrm{C}\right)$. The resultant supernatant was stored while the precipitate was redispersed in water $(200 \mathrm{~mL})$. The process above was repeated and both supernatants were pooled together, concentrated using a vacuum evaporator and freeze-dried. The dried extracts (0.16-250.00 $\mu \mathrm{g} / \mathrm{mL})$ and 4(-2-aminoethyl) benzenesulfonylfluoridehydrochloride (AEBSF, 0.78-25.00 $\mu \mathrm{g} / \mathrm{mL}$ ) were dissolved in $20 \mathrm{mM}$ Tris-HCl buffer ( $\mathrm{pH}$ 7.5). A $200 \mu \mathrm{L}$ aliquot of the sample was mixed with $200 \mu \mathrm{L}$ of trypsin $(270 \mu \mathrm{g} / \mathrm{mL})$ and incubated for $5 \mathrm{~min}$ at $37^{\circ} \mathrm{C}$ and $400 \mathrm{rpm}$ using a thermomixer (Eppendorf AG, Hamburg, Germany). Thereafter, $500 \mu \mathrm{L}$ of $N$-benzoyl-DL-arginine- $p$-nitroanilidehydrochloride (BAPNA, $0.9 \mathrm{mM}$ ) was added and agitated (400 rpm) for $10 \mathrm{~min}$ at $37^{\circ} \mathrm{C}$. The addition of $100 \mu \mathrm{L}$ of acetic acid (30\%) stopped the reaction with continuous shaking $(400 \mathrm{rpm})$ for $5 \mathrm{~min}$ at $37^{\circ} \mathrm{C}$. The absorbance of the mixture was determined in comparison with that of a blank at $410 \mathrm{~nm}$ using a microplate reader Synergy H4 (Biotek Corp., Winooski, VT, USA) coupled with Gen5 2.04 data analysis software. Concentration of extracts required to inhibit $50 \%$ of trypsin activity was estimated using Prism 6 software (GraphPad Corp., La Jolla, USA).

\section{Statistical analysis}

Data were analyzed using $\mathrm{R}$ statistical software version 3.1.0 (The R Foundation for Statistical Computing, Vienna, Austria). Three-way analysis of variance on repeated measures was performed to investigate the main and interaction effects of vegetable species, urea micro-doses, and harvest times on proximate composition, mineral profile, and trypsin-inhibitory activity of the leafy vegetables. Significance was set at 5\% and means were segregated using Duncan's multiple range test.

\section{RESULTS AND DISCUSSION}

Variation in proximate composition of the leafy vegetables

Moisture content was the most abundant component followed by protein, fiber, and fat. The range of moisture content of $S$. macrocarpon $(86.0-90.1 \mathrm{~g} / 100 \mathrm{~g}$ ) was higher than those of A. cruentus (76.7-87.6 g/100 g) and O. gratissimum (79.3-87.4 g/100 g) which are similar to those reported for Justicia tenella and Sesamum radiatum (72.0-83.3 g/100 g) by Sossa-Vihotogbé et al. [2013]. High moisture content is an index of freshness and fast perishability due to the activity of water-soluble enzymes involved in metabolic processes and microbial growth [Vodouhè et al., 2012; Adjatin et al., 2013]. The range for protein and fiber contents of $S$. macrocarpon (27.6-34.1 g/100 g and 16.7-25.5 g/100 g) were higher respectively than those of $A$. cruentus $(21.2-26.3 \mathrm{~g} / 100 \mathrm{~g}$ and $9.8-12.7 \mathrm{~g} / 100 \mathrm{~g}$ ) and $O$. gratissimum $(17.1-26.9 \mathrm{~g} / 100 \mathrm{~g}$ and $13.1-16.7 \mathrm{~g} / 100 \mathrm{~g}$ ) which are comparable to those reported earlier [Sossa-Vihotogbé et al., 2013; Akinwunmi \& Omotayo, 2016] for A. cruentus (17.0 g/100 g and $10.4 \mathrm{~g} / 100 \mathrm{~g})$, J. tenella (17.2-33.8 g/100 g and 8.7-13.1 g/100 g), O. gratissimum $(12.2 \mathrm{~g} / 100 \mathrm{~g}$ and $10.5 \mathrm{~g} / 100 \mathrm{~g})$, and $S$. radiatum (18.8-27.8 g/100 g and 6.9-10.9 g/100 g). Protein contents in leaves $(>12 \mathrm{~g} / 100 \mathrm{~g}$, dwb) suggest their potency as good sources of proteins, which may act as anabolic agents and as alternative sources of energy through gluconeogenesis when carbohydrates metabolism is impaired [Vodouhè et al., 2012; Adjatin et al., 2013]. The potential preventive effects of high fiber contents against gastrointestinal disorders, absorption of excess cholesterol and colon cancer [Vodouhè et al., 2012; Adjatin et al., 2013] suggest that these three species are good candidates for healthy maintenance of the human body.

Fat contents in A. cruentus (1.0-4.0 g/100 g), O. gratissimum (2.7-5.4 g/100 g), and S. macrocarpon (2.6-4.6 g/100 g) were similar and are within the range previously reported [Sossa-Vihotogbé et al., 2013; Akinwunmi \& Omotayo, 2016] for A. cruentus (1.2 g/100 g), S. macrocarpon (3.0 g/100 g), J. tenella, and S. radiatum (1.9-7.3 g/100 g). Conversely, higher fat contents were reported for $O$. gratissimum $(6.6 \mathrm{~g} / 100 \mathrm{~g})$, T. occidentalis $(7.6 \mathrm{~g} / 100 \mathrm{~g})$, and $\mathrm{V}$. amygdalina $(6.0 \mathrm{~g} / 100 \mathrm{~g})$ by Akinwunmi \& Omotayo [2016]. The range of ash recorded for 0 . gratissimum $(14.6-17.8 \mathrm{~g} / 100 \mathrm{~g})$ were lower than those of $A$. cruentus (22.1-24.9 g/100 g) and $S$. macrocarpon (16.6-23.9 g/100 g). The ash contents recorded were higher than that reported [Sossa-Vihotogbé et al., 2013; Akinwunmi \& Omotayo, 2016] for J. tenella (10.4-17.0 g/100 g), O. gratissimum $(5.7 \mathrm{~g} / 100 \mathrm{~g})$, S. radiatum $(7.7-12.3 \mathrm{~g} / 100 \mathrm{~g})$, and T. occidentalis $(11.2 \mathrm{~g} / 100 \mathrm{~g})$ but similar to the values reported for A. cruentus, S. macrocarpon, and V. amygdalina (15.5$-23.1 \mathrm{~g} / 100 \mathrm{~g}$ ) by Akinwunmi \& Omotayo [2016]. Ash content is an index of mineral levels in food products, and it indicates potential health benefits because of the key roles of minerals in various metabolic processes [Adjatin et al., 2013; Bvenura \& Afolayan, 2014a, b].

\section{Proximate composition as linked to vegetable species, urea micro-doses, and harvest times}

There was no significant effect of urea micro-doses (except on moisture content, $\mathrm{p}=0.03$ ) and their interaction with vegetable species and/or harvest times on proximate composition of the leafy vegetables (Table 1). The significantly highest moisture contents were found with the application of $60 \mathrm{~kg}$ / ha of urea $(85.1 \mathrm{~g} / 100 \mathrm{~g})$. Moreover, moisture $(\mathrm{p}=0.02)$ and ash $(\mathrm{p}=0.04)$ contents were significantly influenced by interaction of vegetable species and harvest times (Table 1) with the highest contents recorded at the second harvest of S. macrocarpon (Figure 1a) and at the first harvest of A. cruentus (Figure 1b). Vegetable species had a significant effect on moisture $(p<0.01)$, fat $(p=0.03)$, fibers $(p=0.02)$, protein $(p=0.02)$, and ash $(p<0.01)$ contents while moisture content was significantly $(\mathrm{p}=0.01)$ affected by harvest times (Table 1$)$. The highest fibers and protein contents were recorded with $S$. macrocarpon whereas A. cruentus and O. gratissimum had the highest ash and fat contents, respectively (Table 2). Genotype and its interaction with fertilization type and rate were reported to influence plant responsiveness to nutrient availability [Sossa-Vihotogbé et al., 2013; Fonge et al., 2016]. Thus, the proximate composition of the leafy vegetables was expected to vary with vegetable species, urea micro-doses, and harvest times.

The lack of significant effect of urea micro-doses on proximate composition can be explained by the fertilization method applied. Indeed, high protein contents were related 
TABLE 1. Effect of vegetable species (VS), urea micro-doses (UMD), and harvest times (HT) on proximate composition and mineral profile of the vegetable leaf powders as well as on trypsin-inhibitory activity of vegetable leaf extracts.

\begin{tabular}{|c|c|c|c|c|c|c|c|c|}
\hline \multirow{2}{*}{ Variables } & & \multicolumn{3}{|c|}{ Main factors } & \multicolumn{4}{|c|}{ Interaction between factors } \\
\hline & & VS & UMD & HT & VSxUMD & VSxHT & UMDxHT & VSxUMDxHT \\
\hline \multirow{5}{*}{$\begin{array}{l}\text { Proximate } \\
\text { composition }\end{array}$} & Moisture & $4696.2 \beta^{* *}$ & $487.1^{*}$ & $12702.9^{* *}$ & 146.5 & $648.7^{*}$ & 53.1 & 61.2 \\
\hline & Fat & $543.0^{*}$ & 26.3 & 27.4 & 33.8 & 40.9 & 18.6 & 22.4 \\
\hline & Fibers & $1382.8^{*}$ & 23.6 & 30.9 & 21.7 & 770.3 & 73.5 & 11.3 \\
\hline & Protein & $1371.6^{*}$ & 3.6 & 0.2 & 3.0 & 98.8 & 1.7 & 7.1 \\
\hline & Ash & $5618.2^{* * *}$ & 2.9 & 122.9 & 30.9 & $303.4^{*}$ & 50.2 & 64.8 \\
\hline \multirow{10}{*}{$\begin{array}{l}\text { Major minerals } \\
\text { and their ratios }\end{array}$} & Calcium & 124.5 & 8.3 & $1596.7^{*}$ & 16.4 & $198.7^{*}$ & 2.8 & 7.1 \\
\hline & Magnesium & $3089.7^{*}$ & 10.7 & 135.1 & 69.0 & 205.1 & 7.1 & 12.8 \\
\hline & Phosphorus & $2107.9^{*}$ & 9.6 & 0.6 & 0.8 & 133.7 & 12.3 & 2.9 \\
\hline & Potassium & $186.1^{*}$ & 28.6 & 11.0 & 11.4 & 160.9 & 3.3 & 10.5 \\
\hline & Sodium & $710.7^{*}$ & 3.4 & 5.2 & 2.6 & 3.5 & 7.8 & 9.4 \\
\hline & Calcium/magnesium & $217.2^{*}$ & 12.6 & 8.8 & 2.2 & 45.7 & 5.6 & 8.6 \\
\hline & Calcium/phosphorus & $1427.1^{*}$ & 25.9 & $1584.9^{*}$ & 19.4 & $349.3^{*}$ & 34.9 & 13.9 \\
\hline & Calcium/potassium & $504.5^{*}$ & 11.2 & $612.1^{*}$ & 5.0 & $412.9^{*}$ & 4.0 & 1.9 \\
\hline & Sodium/magnesium & $687.2^{*}$ & 27.3 & 2.3 & 2.4 & 2.6 & 12.8 & 3.9 \\
\hline & Sodium/potassium & $1389.6^{*}$ & 17.1 & 6.7 & 4.9 & 0.8 & 14.8 & 5.4 \\
\hline \multirow{6}{*}{$\begin{array}{l}\text { Trace minerals } \\
\text { and their ratios }\end{array}$} & Copper & $4675.1^{* * *}$ & 3.5 & $188.3^{*}$ & 0.9 & $493.3^{*}$ & 6.6 & 4.9 \\
\hline & Iron & $6885.1^{* * *}$ & 49.5 & $564.9^{*}$ & 17.8 & $205.4^{*}$ & 8.1 & 17.1 \\
\hline & Manganese & $2477.3^{*}$ & 28.8 & $382.5^{*}$ & 45.5 & 86.9 & 9.6 & 17.1 \\
\hline & Zinc & $579.1^{*}$ & $179.5^{*}$ & $152.2^{*}$ & 42.7 & $567.5^{*}$ & 99.1 & 42.0 \\
\hline & Iron/copper & $1609.8^{*}$ & 152.4 & $249.5^{*}$ & 281.8 & $266.3^{*}$ & 10.2 & 23.3 \\
\hline & Zinc/copper & $2101.9^{*}$ & 71.3 & $274.0^{*}$ & 78.7 & $1535.3^{*}$ & 91.1 & 58.7 \\
\hline Trypsin inhibition & & $1692.5^{* * * *}$ & $37.4^{*}$ & 4.2 & 13.4 & 15.9 & $165.2^{\text {** }}$ & $180.4^{* *}$ \\
\hline
\end{tabular}

VS is used for the three vegetable species (A. cruentus, O. gratissimum and S. macrocarpon), UMD correspond to the four urea micro-doses (0, 20, 40, and $60 \mathrm{~kg} / \mathrm{ha}$ ) and HT indicate the three successive harvests of $A$. cruentus (4, 6 and 8 weeks after transplanting, respectively), of $O$. gratissimum (8, 12, and 16 weeks after transplanting, respectively) and of $S$. macrocarpon $(6,10$ and 14 weeks after transplanting, respectively). $\beta$ : F-value. Significance: $* \mathrm{p}<0.05,{ }^{* *} \mathrm{p}<0.01,{ }^{* * *} \mathrm{p}<0.001$.

to sufficient nitrogen and moisture contents in the soil, which increase nutrient uptake by plants, plant growth, and synthesis of nitrogen-based compounds [Souza et al., 2016]. Moreover, urea micro-dosing optimizes nitrogen application in order to avoid any nitrogen deficiency while ensuring adequate uptake by the root system [Tovihoudji et al., 2017; Likpètè et al., 2019]. Likewise, higher ash contents recorded when compared to those previously reported [Sossa-Vihotogbé et al., 2013; Akinwunmi \& Omotayo, 2016] suggest that urea micro-dosing has promoted plant nutrients uptake, despite the lack of direct relation between urea micro-doses and ash contents. Given that the application of organic fertilizer increases synthesis of carbon-based compounds including fibers [Fonge et al., 2016; Souza et al., 2016; Das et al., 2017], the lack of effect of urea micro-doses on fiber and protein contents indicates that the based organic fertilizer contributed to a sufficient level of organic nitrogen [Souza et al., 2016].
The significant effects of harvest times on proximate composition agreed with findings of Sossa-Vihotogbé et al. [2013] for $J$. tenella and S. radiatum leaves and could be linked to the occurrence of structural changes within plants over time [Sossa-Vihotogbé et al., 2013].

\section{Mineral profile and its potential effects on human micronutrient status}

Potassium and calcium were the most abundant major minerals found in A. cruentus (4.2-6.8 g/100 $\mathrm{g}$ and $2.7-5.0 \mathrm{~g} / 100 \mathrm{~g}$ ), O. gratissimum (3.9-4.8 g/100 g and $2.1-2.9 \mathrm{~g} / 100 \mathrm{~g}$ ), and S. macrocarpon (5.1-8.2 g/100 g and 2.2-3.8 g/100 g) followed by magnesium (A. cruentus: $1.0-1.6 \mathrm{~g} / 100 \mathrm{~g}, O$. gratissimum: $0.4-0.6 \mathrm{~g} / 100 \mathrm{~g}$, S. macrocarpon: $0.5-1.0 \mathrm{~g} / 100 \mathrm{~g}$ ), phosphorus (A. cruentus: $0.3-0.4 \mathrm{~g} / 100 \mathrm{~g}$, O. gratissimum: $0.4-0.6 \mathrm{~g} / 100 \mathrm{~g}$, S. macrocarpon: $0.5-0.8 \mathrm{~g} / 100 \mathrm{~g})$, and sodium $(<0.1 \mathrm{~g} / 100 \mathrm{~g})$. The levels of specific minerals in the vegetables are similar to 
values reported for calcium (1.2-4.0 g/100 g), magnesium (0.3-0.9 g/100 g), phosphorus (0.2-0.8 g/100 g), potassium (3.9-7.0 g/100 g), and sodium (0.02-1.5 g/100 g) in Solanum nigrum [Bvenura \& Afolayan, 2014a] whereas lower contents $(<0.1 \mathrm{~g} / 100 \mathrm{~g})$ were reported for $A$. cruentus, $O$. gratissimum, and $S$. macrocarpon [Akinwunmi \& Omotayo, 2016]. Iron and manganese were the most abundant trace minerals determined in A. cruentus (271.3-971.9 mg/kg and 501.2 -976.4 mg/kg, respectively), O. gratissimum $(132.6-442.2 \mathrm{mg} / \mathrm{kg}$ and $89.8-125.6 \mathrm{mg} / \mathrm{kg}$, respectively), and $S$. macrocarpon (153.8-606.3 mg/kg and $109.6-213.9 \mathrm{mg} / \mathrm{kg}$, respectively) followed by zinc (A. cruentus: $41.7-171.1 \mathrm{mg} / \mathrm{kg}$, O gratissimum: $34.5-78.5 \mathrm{mg} / \mathrm{kg}$, S. macrocarpon: $41.9-661.6 \mathrm{mg} / \mathrm{kg}$ ) and copper (A. cruentus: $7.2-11.2 \mathrm{mg} / \mathrm{kg}, O$. gratissimum: 11.8 $-30.3 \mathrm{mg} / \mathrm{kg}$, S. macrocarpon: $13.5-27.4 \mathrm{mg} / \mathrm{kg}$ ). The ranges of iron and copper in the vegetables fit with values previously reported [Bvenura \& Afolayan, 2014b; Akinwunmi \& Omotayo, 2016] for $S$. macrocarpon (403.1 mg/kg and $12.8 \mathrm{mg} / \mathrm{kg}$ ), S. nigrum (178.0-766.0 mg/kg and 7.2-23.5 mg/kg), and V. amygdalina $(467.9 \mathrm{mg} / \mathrm{kg}$ and $25.5 \mathrm{mg} / \mathrm{kg})$. Zinc contents are similar to those reported for $O$. gratissimum $(44.7 \mathrm{mg} / \mathrm{kg})$ and $S$. nigrum $(19.0-78.0 \mathrm{mg} / \mathrm{kg})$ but lower than those of A. cruentus $(951.5 \mathrm{mg} / \mathrm{kg})$ and T. occidentalis $(1023.1 \mathrm{mg} / \mathrm{kg})$ [Bvenura \& Afolayan, 2014b; Akinwunmi \& Omotayo, 2016]. Manganese contents in $A$. cruentus were higher than values reported [Akinwunmi \& Omotayo 2016] for O. gratissimum $(4.5 \mathrm{mg} / \mathrm{kg})$ and $S$. macrocarpon $(49.6 \mathrm{mg} / \mathrm{kg})$.
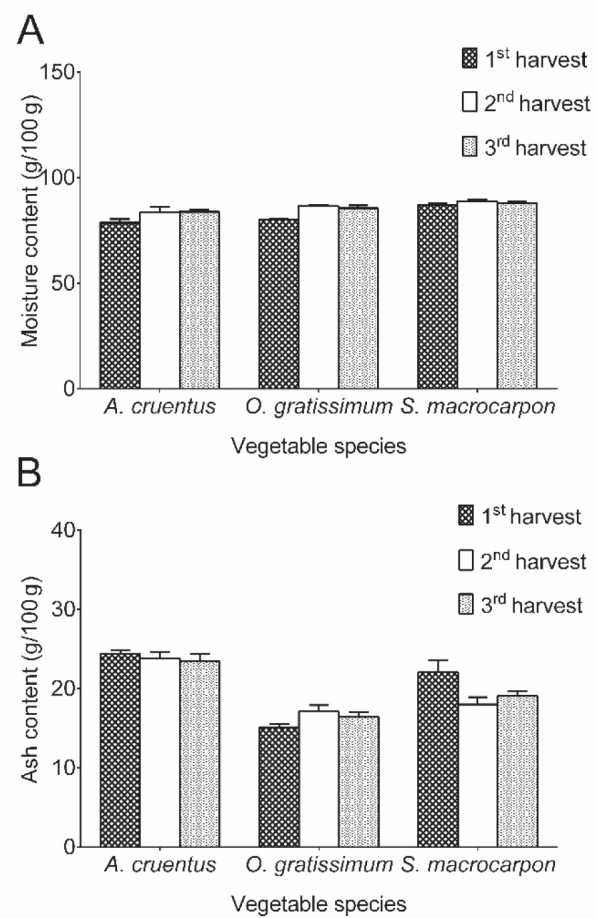

FIGURE 1. Variations in moisture (A) and ash (B) contents of the leafy vegetable species produced with four urea micro-doses $(0,20,40$, and $60 \mathrm{~kg} / \mathrm{ha}$ ) depending on harvest times.

Results are expressed on dry weight basis (except for moisture content). $1^{\text {st }}, 2^{\text {nd }}$, and $3^{\text {rd }}$ harvests correspond to 4,6 , and 8 weeks after transplanting, respectively for $A$. cruentus; 8,12 , and 16 weeks after transplanting, respectively for $O$. gratissimum and 6, 10, and 14 weeks after transplanting, respectively for $S$. macrocarpon.
Mean values for calcium, copper, iron, magnesium, phosphorus, potassium, and zinc are higher than their recommended daily intakes (RDI) for children and adults [Trumbo et al., 2001; Sawka, 2005; Bergman et al., 2009]. Thus, consumption of these vegetables could improve human micronutrient status although high quantities (100-300 g) of dried leaf powders must be consumed to meet the RDI. Conversely, our values for sodium and manganese contents are lower than the RDI for children and adults [Trumbo et al., 2001; Sawka, 2005], suggesting that these vegetables are poor-sodium and -manganese sources. Considering that sauces that accompany starchy staple foods are currently the common consumption forms of these vegetables [Dansi et al., 2008; Vodouhè et al., 2012], it is likely that the quantities of the vegetables (either leaf powders or fresh leaves) required to meet these RDI cannot be easily consumed in a day. Thus, a diversification of vegetables consumption forms is needed to improve individual nutritional profile.

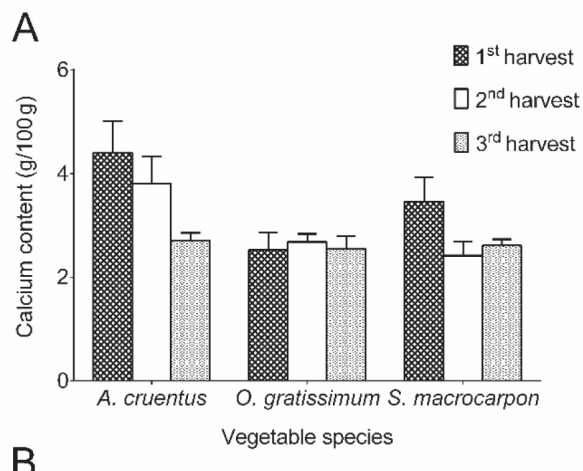

B
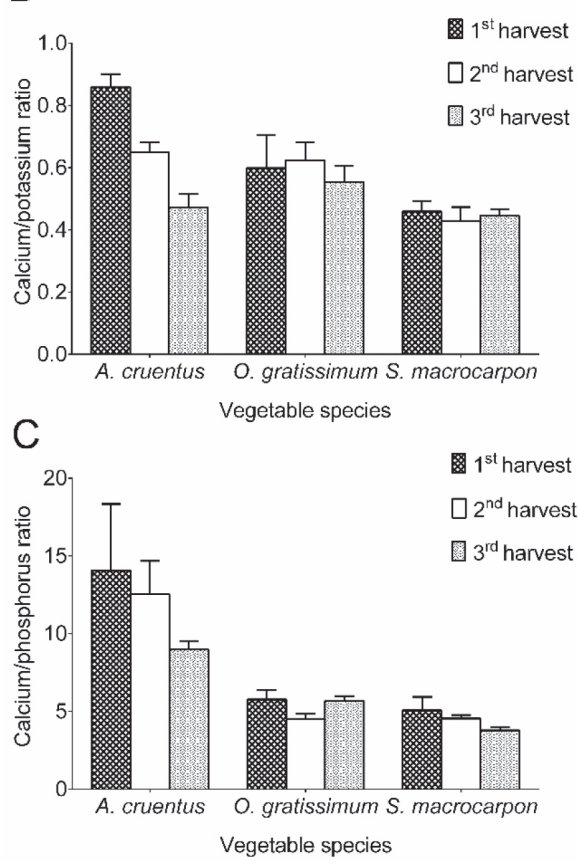

FIGURE 2. Variations in calcium content (A), calcium/potassium ratio (B) and calcium/phosphorus ratio (C) of the leafy vegetable species produced with four urea micro-doses $(0,20,40$, and $60 \mathrm{~kg} / \mathrm{ha}$ ) depending on harvest times.

Results are expressed on dry weight basis. $1^{\text {st }}, 2^{\text {nd }}$ and $3^{\text {rd }}$ harvests correspond to 4, 6 and 8 weeks after transplanting, respectively for $A$. cruentus; 8,12 , and 16 weeks after transplanting, respectively for $O$. gratissimum and 6,10 , and 14 weeks after transplanting, respectively for $S$. macrocarpon. 


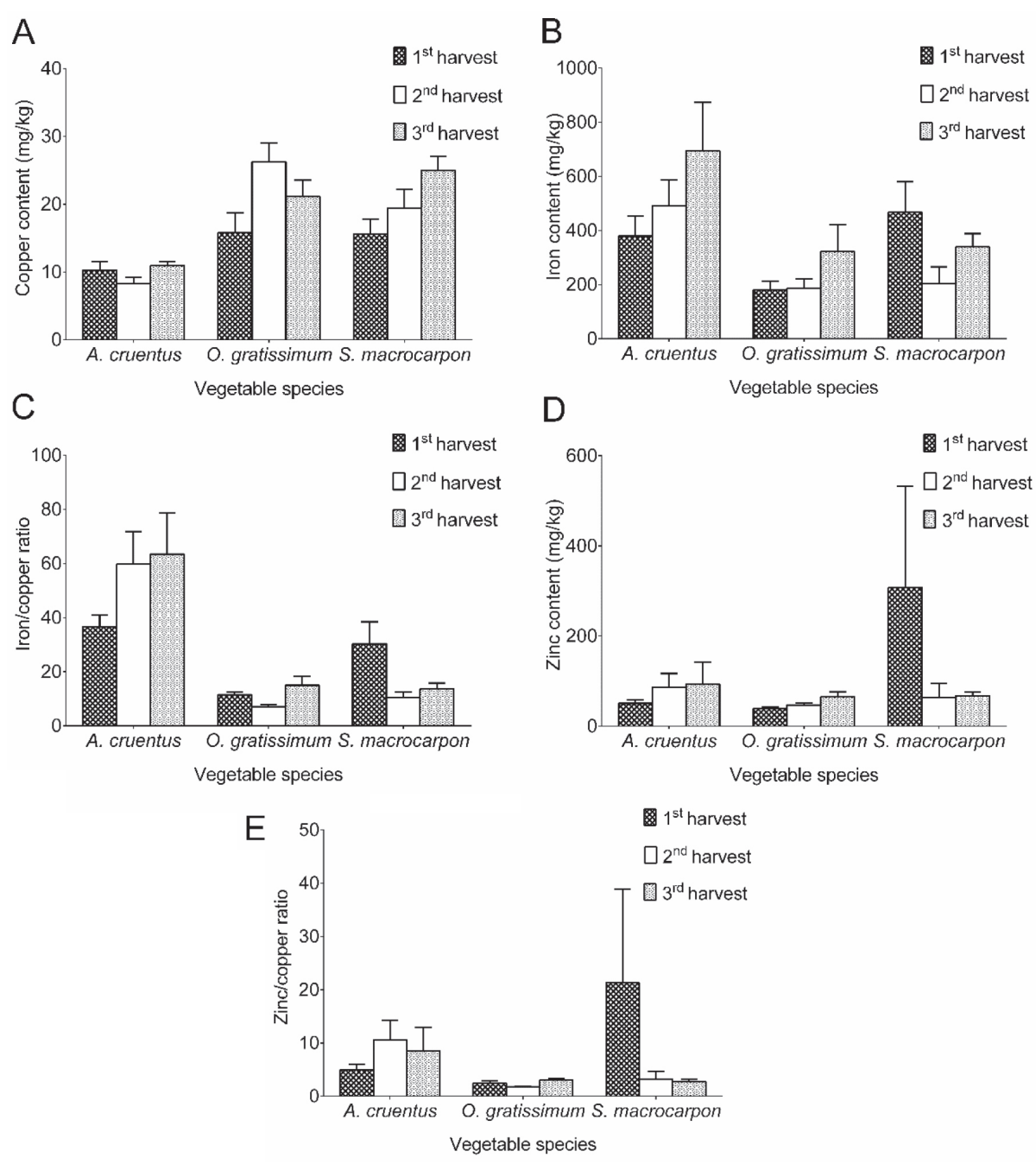

FIGURE 3. Variations in iron (A), zinc (B) and copper (C) contents as well as in iron/copper (D) and zinc/copper (E) ratios of the leafy vegetable species produced with four urea micro-doses $(0,20,40$, and $60 \mathrm{~kg} / \mathrm{ha})$ depending on harvest times.

Results are expressed on dry weight basis. $1^{\text {st }}, 2^{\text {nd }}$ and $3^{\text {rd }}$ harvests correspond to 4,6 , and 8 weeks after transplanting, respectively for $A$. cruentus; 8,12 , and 16 weeks after transplanting, respectively for $O$. gratissimum and 6,10, and 14 weeks after transplanting, respectively for $S$. macrocarpon .

\section{Mineral ratios and their potential effects on human health disorders}

The calcium/magnesium and calcium/phosphorus ratios of A. cruentus (2.3-3.5 and 8.3-18.3, respectively), O. gratissimum (4.6-6.2 and 4.3-6.4, respectively), and S. macrocarpon (2.6-4.5 and 3.6-6.2, respectively) were higher than their calcium/potassium (A. cruentus: $0.5-0.9$, O. gratissimum: $0.5-$ -0.7 and $S$. macrocarpon: $0.4-0.5)$, sodium/magnesium $(<0.1)$, and sodium/potassium $(<0.1)$ ratios. The calcium/magnesium ratios are below (A. cruentus) or within (O. gratissimum and S. macrocarpon) the acceptable range of 3-11 [Watts, 2010], indicating potency for low or balanced glucose metabolism, which is inversely associated with the risk of type 2 diabetes [Watts, 2010]. Inversely, the calcium/phosphorus ratios (>1.8-3.6) of these vegetables may increase intestinal absorption of calcium, which is useful for the formation of strong bones and teeth [Watts, 2010; Adjatin et al., 2013] but the calcium/potassium ratios $(<2.2-6.2)$ could promote hyperthyroidism and its related complications [Watts, 2010]. The sodium/magnesium $(<2-6)$ and sodium/potassium $(<1.4-3.4)$ ratios associated with these vegetables could contribute to high blood pressure lowering and anti-inflammatory activities [Watts, 2010; Adjatin et al., 2013]. The iron/copper ratio of A. cruentus (31.7-87.9), and $O$. gratissimum $(6.3-18.5)$ were higher than their zinc/copper ratio (A. cruentus: 4.0-15.5 and O. gratissimum: 1.7-3.3). A wide range was found for zinc/copper ratio of $S$. macrocarpon (2.3-49.0) when compared to its iron/copper ratio (8.3-42.9). The iron/copper $(>0.2-1.6)$ and zinc/copper $(>4-12)$ ratios observed may increase the risk of oxidative stress-related diseases because of the key role of these ratios in the maintenance of the oxidant/antioxidant balance [Watts, 2010]. The values of iron/copper ratio may also affect iron utilization by decreasing its incorporation into hemoglobin and promoting anemia [Watts, 2010]. These findings indicate that some adjustments (preferably by food-to-food fortification) are needed to avoid the adverse effects predicted for calcium/potassium, iron/copper, and zinc/copper ratios.

\section{Mineral composition as affected by vegetable species, urea micro-doses and harvest times}

The effect of urea micro-doses (except for zinc content, $\mathrm{p}=0.04$ ) and their interaction with vegetable spe- 
cies and/or harvest times were not significant $(p>0.05)$ for the mineral contents and ratios (Table 1). Given that ash content is an index of mineral levels, the lack of significant influence of urea micro-doses and of their interaction with other factors on the mineral profile was expected due to the lack of direct relation between urea micro-doses and ash contents in this study. Vegetable species, harvest times, and their interaction had respectively significant effects on copper $(p<0.01, p=0.04$ and $p=0.03)$, iron $(p<0.01$, $p=0.03$ and $p=0.04)$, and zinc $(p=0.03, p=0.04$ and $p=0.03)$ contents as well as on calcium/phosphorus $(p=0.02$, $p=0.02$ and $p=0.03)$, calcium/potassium $(p=0.03)$, iron/copper $(\mathrm{p}=0.02, \mathrm{p}=0.04$ and $\mathrm{p}=0.04)$, and zinc/copper $(\mathrm{p}=0.01$, $p=0.04$ and $p=0.02$ ) ratios (Table 1 ). Harvest time and its interaction with vegetable species had significant effects on calcium content ( $p=0.02$ and $p=0.04$, respectively) (Table 1 ). The interaction of vegetable species and harvest times revealed that the first harvest of $A$. cruentus had the highest calcium content (Figure 2a), calcium/potassium ratio (Figure 2b), and calcium/phosphorus ratio (Figure 2c). The highest copper content was recorded at the second harvest of $O$. gratissimum (Figure 3a) whereas the third harvest of $A$. cruentus had the highest iron content (Figure 3b) and iron/copper ratio (Figure 3c). Conversely, the highest zinc content (Figure 3d) and zinc/copper ratio (Figure $3 \mathrm{e}$ ) were recorded at the first harvest of $S$. macrocarpon. Significant effect of harvest time was recorded for manganese content $(p=0.03)$ (Table 1), with the highest content found at the first $(339.8 \mathrm{mg} / \mathrm{kg})$ and the second $(330.5 \mathrm{mg} / \mathrm{kg})$ harvests.

Vegetable species had a significant effect on magnesium $(p=0.01)$, manganese $(p=0.01)$, phosphorus $(p=0.01)$, potassium $(p=0.04)$, and sodium $(p=0.02)$ contents as well as on calcium/magnesium $(p=0.04)$, calcium/phosphorus $(\mathrm{p}=0.02)$, calcium/potassium $(\mathrm{p}=0.03)$, sodium $/$ magnesium $(p=0.02)$, and sodium/potassium $(p=0.02)$ ratios (Table 1$)$. The highest magnesium, manganese, and sodium contents as well as sodium/magnesium and sodium/potassium ratios were found in A. cruentus (Table 2). Phosphorus content was the highest in $S$. macrocarpon while $O$. gratissimum had the highest calcium/magnesium ratio (Table 2). Higher potassium contents were found in A. cruentus and S. macrocarpon (Table 2). Plant growth depends greatly on water and nutrient availability in the soil and their uptake by the root system depending on plants' developmental stage although genotype and its interaction with fertilization type and rate influence plant responsiveness to nutrient availability [Sossa-Vihotogbé et al., 2013; Fonge et al., 2016]. Mineral fertilization supplies plants in readily available nutrients unlike organic fertilization, which delays nutrients release and availability due to slow mineralization [Souza et al., 2016; Das et al., 2017]. Thus, variation in the rate of nutrients availability into the soil and their uptake by plants may explain the significant differences observed in calcium content and trace mineral profile according to harvest time. The decrease in calcium content with increase of harvest time could be linked to the immobility of this mineral once taken up into plants tissues, which stops its translocation from older to growing parts of the plants [Bvenura \& Afolayan, 2014a, b] while that of zinc contents may be linked to zinc accumulation in young plants [Bvenura
TABLE 2. Effect of vegetable species on proximate and mineral compositions of the leafy vegetables produced with four urea micro-doses and harvested three successive times.

\begin{tabular}{|c|c|c|c|c|}
\hline Variables & & $\begin{array}{c}\text { Amaranthus } \\
\text { cruentus }\end{array}$ & $\begin{array}{c}\text { Ocimum } \\
\text { gratissimum }\end{array}$ & $\begin{array}{c}\text { Solanum } \\
\text { macrocarpon }\end{array}$ \\
\hline \multirow{5}{*}{$\begin{array}{l}\text { Proximate } \\
\text { composition }^{1}\end{array}$} & Moisture & $82.0 \pm 0.1 \beta^{\mathrm{c}}$ & $84.1 \pm 0.0^{\mathrm{b}}$ & $87.9 \pm 0.0^{\mathrm{a}}$ \\
\hline & Fat & $2.2 \pm 0.1^{\mathrm{c}}$ & $4.2 \pm 0.0^{\mathrm{a}}$ & $3.2 \pm 0.0^{\mathrm{b}}$ \\
\hline & Fibers & $11.4 \pm 0.2^{\mathrm{c}}$ & $14.6 \pm 0.0^{b}$ & $20.4 \pm 0.0^{\mathrm{a}}$ \\
\hline & Protein & $23.6 \pm 0.1^{\mathrm{b}}$ & $22.2 \pm 0.0^{c}$ & $30.3 \pm 0.2^{\mathrm{a}}$ \\
\hline & Ash & $23.9 \pm 0.0^{\mathrm{a}}$ & $16.2 \pm 0.0^{c}$ & $19.7 \pm 0.1^{b}$ \\
\hline \multirow{10}{*}{$\begin{array}{l}\text { Major } \\
\text { minerals }{ }^{1} \\
\text { and their } \\
\text { ratios }\end{array}$} & Calcium & $3.6 \pm 0.0^{\mathrm{a}}$ & $2.6 \pm 0.1^{\mathrm{a}}$ & $2.8 \pm 0.0^{\mathrm{a}}$ \\
\hline & Magnesium & $1.2 \pm 0.0^{\mathrm{a}}$ & $0.5 \pm 0.0^{c}$ & $0.8 \pm 0.0^{\mathrm{b}}$ \\
\hline & Phosphorus & $0.3 \pm 0.0^{c}$ & $0.5 \pm 0.0^{\mathrm{b}}$ & $0.6 \pm 0.0^{\mathrm{a}}$ \\
\hline & Potassium & $5.6 \pm 0.0^{\mathrm{a}}$ & $4.4 \pm 0.0^{\mathrm{b}}$ & $6.3 \pm 0.1^{\mathrm{a}}$ \\
\hline & Sodium & $0.1 \pm 0.0^{\mathrm{a}}$ & $0.0 \pm 0.0^{\mathrm{b}}$ & $0.0 \pm 0.0^{\mathrm{b}}$ \\
\hline & $\begin{array}{l}\text { Calcium/ } \\
\text { magnesium }\end{array}$ & $3.0 \pm 0.0^{c}$ & $5.4 \pm 0.1^{\mathrm{a}}$ & $3.6 \pm 0.0^{\mathrm{b}}$ \\
\hline & $\begin{array}{c}\text { Calcium/ } \\
\text { phosphorus }\end{array}$ & $11.9 \pm 0.1^{\mathrm{a}}$ & $5.3 \pm 0.1^{b}$ & $4.5 \pm 0.0^{\mathrm{b}}$ \\
\hline & $\begin{array}{l}\text { Calcium/ } \\
\text { potassium }\end{array}$ & $0.7 \pm 0.0^{\mathrm{a}}$ & $0.6 \pm 0.0^{\mathrm{a}}$ & $0.4 \pm 0.0^{\mathrm{b}}$ \\
\hline & $\begin{array}{l}\text { Sodium/ } \\
\text { magnesium }\end{array}$ & $0.1 \pm 0.0^{\mathrm{a}}$ & $0.0 \pm 0.0^{\mathrm{b}}$ & $0.0 \pm 0.0^{\mathrm{b}}$ \\
\hline & $\begin{array}{l}\text { Sodium/ } \\
\text { potassium }\end{array}$ & $0.1 \pm 0.0^{\mathrm{a}}$ & $0.0 \pm 0.0^{\mathrm{b}}$ & $0.0 \pm 0.0^{\mathrm{b}}$ \\
\hline \multirow{6}{*}{$\begin{array}{l}\text { Trace } \\
\text { minerals }{ }^{2} \\
\text { and their } \\
\text { ratios }\end{array}$} & Copper & $9.8 \pm 0.2^{b}$ & $21.1 \pm 0.2^{\mathrm{a}}$ & $20.0 \pm 0.1^{\mathrm{a}}$ \\
\hline & Iron & $521.9 \pm 4.9^{\mathrm{a}}$ & $229.7 \pm 8.4^{c}$ & $337.0 \pm 7.4^{\mathrm{b}}$ \\
\hline & Manganese & $694.7 \pm 11.5^{\mathrm{a}}$ & $106.7 \pm 0.1^{\mathrm{c}}$ & $154.2 \pm 0.2^{\mathrm{b}}$ \\
\hline & Zinc & $77.1 \pm 0.0^{\mathrm{b}}$ & $50.2 \pm 0.9^{c}$ & $146.5 \pm 1.1^{\mathrm{a}}$ \\
\hline & Iron/copper & $53.3 \pm 0.7^{\mathrm{a}}$ & $11.2 \pm 0.3^{\mathrm{c}}$ & $18.1 \pm 0.4^{b}$ \\
\hline & Zinc/copper & $8.1 \pm 0.3^{b}$ & $2.4 \pm 0.0^{c}$ & $9.1 \pm 0.2^{\mathrm{a}}$ \\
\hline
\end{tabular}

Units: ${ }^{1} \mathrm{~g} / 100 \mathrm{~g} ;{ }^{2} \mathrm{mg} / \mathrm{kg}$. Results are expressed on dry weight basis (except for moisture content). $\beta$ : Mean values \pm standard error. Mean values with different alphabets within the same row are significantly different $(\mathrm{p}<0.05)$.

\& Afolayan, 2014b]. The increase in iron and copper contents with increase of harvest time could be related to high organic matter concentration into the soil that promotes a continuous release of easily absorbable minerals into the soil thereby, enhancing their uptake by plants and their contents in leaves as plants matured [Bvenura \& Afolayan, 2014a, b].

\section{Trypsin inhibition as related to vegetable species, urea micro-doses, and harvest times}

The $\mathrm{IC}_{50}$ value of AEBSF $(3.7 \mu \mathrm{g} / \mathrm{mL})$ was lower than that of A. cruentus (0.2-0.3 mg/mL), O. gratissimum $(<0.1 \mathrm{mg} / \mathrm{mL})$, and $S$. macrocarpon $(0.0-4.8 \mathrm{mg} / \mathrm{mL})$. Values recorded for trypsin inhibition from Juglans regia $(42.6 \mu \mathrm{g} / \mathrm{mL})$ and Prunus spinosa $(970.2 \mu \mathrm{g} / \mathrm{mL})$ by Jedinak et al. [2010] and for Justicia gendarussa $(13.4 \mu \mathrm{g} / \mathrm{mL})$ by Patel \& Zaveri [2015] are within the range found for $S$. macrocarpon and $O$. gratissimum. There were significant $(\mathrm{p}<0.01)$ effects of the interaction of vegeta- 


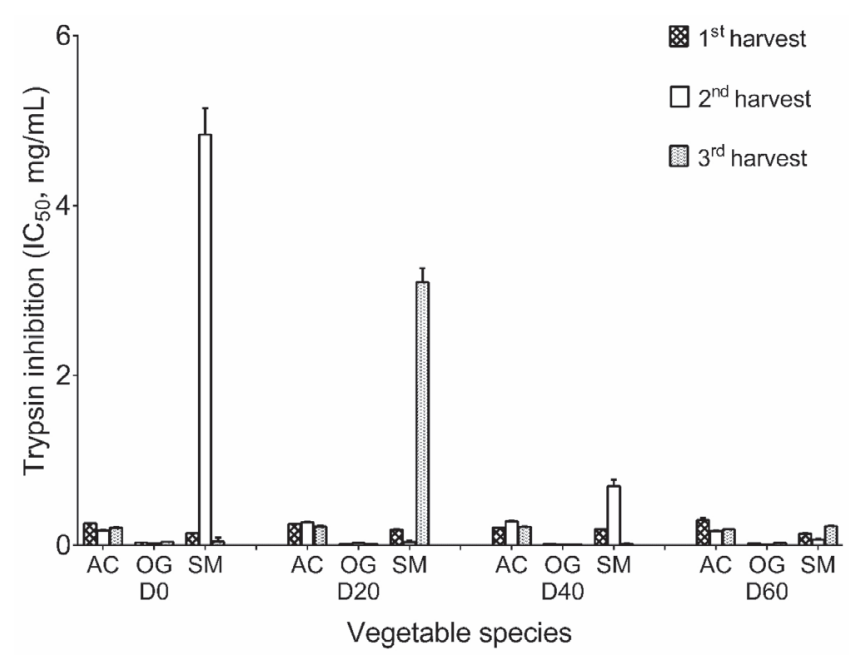

FIGURE 4. Trypsin-inhibitory activity of aqueous vegetable leaf extracts produced with four urea micro-doses and harvested at different times.

A. cruentus, $O$. gratissimum and $S$. macrocarpon were respectively coded AC, OG and SM; D0, D20, D40, and D60 indicate applied urea doses (0, 20,40 , and $60 \mathrm{~kg} / \mathrm{ha}$, respectively); $1^{\text {st }}, 2^{\text {nd }}$, and $3^{\text {rd }}$ harvests correspond to 4,6 , and 8 weeks after transplanting, respectively for A. cruentus; 8, 12, and 16 weeks after transplanting, respectively for $O$. gratissimum and 6 , 10 , and 14 weeks after transplanting, respectively for $S$. macrocarpon.

ble species, urea micro-doses, and harvest times on $\mathrm{IC}_{50}$ values for trypsin inhibition by aqueous leaf extracts (Table 1). The lowest $\mathrm{IC}_{50}$ for trypsin inhibition by $A$. cruentus and $O$. gratissimum extracts were obtained from the samples produced with $60 \mathrm{~kg} / \mathrm{ha}$ of urea and harvested the second time while that of $S$. macrocarpon was from the sample cultivated with $40 \mathrm{~kg} / \mathrm{ha}$ of urea and collected at the third harvest (Figure 4). Irrespective of vegetable species, urea micro-doses and harvest times, the lowest $\mathrm{IC}_{50}$ value was recorded for $O$. gratissimum (Figure 4). The interactive effect of vegetable species, urea micro-doses, and harvest times on the trypsin inhibitions was not expected considering that trypsin inhibitors are usually protein molecules and that there was no evidence of such an interactive effect on protein contents. The interactive effect confirmed the beneficial role of fertilization on the synthesis of nitrogen-based compounds [Souza et al., 2016], including trypsin inhibitors. Plants synthesize protease inhibitors during their normal ontogeny and as a wound-activated response to mechanical wounding [Clemente et al., 2019]. Thus, plant cutting (at harvest) activates stress of mechanical wounding and the up-regulation of genes encoding for synthesis of protease inhibitors [Clemente et al., 2019], thereby leading to the lowest trypsin $\mathrm{IC}_{50}$ value at the third harvest $(S$. macrocarpon). The lowest $\mathrm{IC}_{50}$ found at the second harvest of $A$. cruentus and $O$. gratissimum could have resulted from a species-specific response to a high urea dose $(60 \mathrm{~kg} / \mathrm{ha})$ and mechanical wounding at harvests. The first harvest has probably caused physiological stress that enhanced the synthesis of the trypsininhibitory protein molecules.

The activity of trypsin inhibitors of products from plant origin were reported to markedly increase after heat treatment at $60^{\circ} \mathrm{C}$ while a loss of activity occurred above $60^{\circ} \mathrm{C}$ and the decreasing rate depended on the type of the heat treatment applied (dry or moist) [Allen et al., 2012; Pesoti et al.,
2015]. Indeed, a less decreasing rate was recorded for dry-heated products with an average loss of $10 \%$ of activity when temperature increase by $20^{\circ} \mathrm{C}$ whereas a rapid decreasing rate occurred for the moist-heated products (loss of $45 \%$ of activity from 60 to $80^{\circ} \mathrm{C}$ and of $20 \%$ of activity from 80 to $100^{\circ} \mathrm{C}$ ) [Allen et al., 2012]. Based on these findings, we can assert that oven-drying (at $60^{\circ} \mathrm{C}$ ) of the studied leaves and the aqueous extraction of dry leaf powder $\left(\right.$ at $60^{\circ} \mathrm{C}$ ) did not inactivate their trypsin inhibitors. Regardless of the applied heat treatment type, the trypsin inhibitors are rapidly inactivated by very high temperatures $\left(>100^{\circ} \mathrm{C}\right.$ ) [Allen et al., 2012; Pesoti et al., 2015]. Given that the studied vegetables are usually consumed in sauce and that their cooking temperature is very high $\left(>100^{\circ} \mathrm{C}\right)$, we may assume that trypsin inhibitors could be inactivated by the moist heat treatment, which has been shown to provide better inactivation of trypsin inhibitors than dry heat treatment [Allen et al., 2012; Pesoti et al., 2015]. However, to the best of knowledge, there is no scientific report on the effect of heat treatment on the status of the trypsin inhibitors in sauces made with the studied leafy vegetables. Considering that various ingredients are combined during cooking, there is a need for further studies that will explore the complexity of biochemical reactions occurring during cooking in order to provide clear answers regarding the inactivation of trypsin inhibitors in leafy vegetables during sauces preparation.

\section{CONCLUSION}

This study highlighted the nutritional properties of leafy vegetables produced using urea micro-doses and harvested at different times. Consumption of $A$. cruentus leaves could improve diets quality due to their high mineral contents while the richness of $S$. macrocarpon leaves in fibers could facilitate digestion and reduce the potential for colon carcinogenesis. The effects of vegetable species and harvest times were more marked than that of urea micro-doses and uphold the recommendation of early (the first two) harvests for the vegetable species in order to fully benefit from their high nutritional properties. The aqueous leaf extracts had potent trypsin inhibition; a useful nutraceutical property for the management of high energy intake diets and of disease conditions associated with excessive protein catabolism. Moreover, the trypsin-inhibitory activity may be helpful against virus-dependent diarrhea. However, the nutritional and functional properties exhibited by the studied vegetables were based on in vitro assays and should be confirmed by in vivo animal and human trials.

\section{ACKNOWLEDGEMENTS}

The authors would like to thank graduate students and other colleagues who worked on the experimental fields that produced the vegetables.

\section{RESEARCH FUNDING}

This work was supported by the International Development Research Centre (IDRC) and Global Affairs Canada, through the Canadian International Food Security Research Fund (CIFSRF) Project No. 107983 under IDRC Grant [No. 107983-003]. 


\section{CONFLICT OF INTEREST}

The authors declare that they have no conflict of interest.

\section{REFERENCES}

1. Adewale, O.B., Onasanya, A., Fadaka, O.A., Iwere, H., Anadozie, S.O., Osukoya, A.O., Olayide, I.I. (2014). In vitro antioxidant effect of aqueous extract of Solanum macrocarpon leaves in rat liver and brain. Oxidants and Antioxidants in Medical Sciences, 3(3), 225-229.

2. Adjatin, A., Dansi, A., Badoussi, E., Sanoussi, A.F., Dansi, M., Azokpota, P., Ahissou, H., Akouegninou, A., Akpagana, K., Sanni, A. (2013). Proximate, mineral and vitamin C composition of vegetable Gbolo [Crassocephalum rubens (Juss. ex Jacq.) S. Moore and C. crepidioides (Benth.) S. Moore] in Benin. International Journal of Biological and Chemical Sciences, 7(1), 319-331.

3. Akinwunmi, O.A., Omotayo, F.O. (2016). Proximate analysis and nutritive values of ten common vegetables in South-West (Yoruba land) Nigeria. Communications in Applied Sciences, 4(2), 79-91.

4. Allen, J.C., Corbitt, A.D., Maloney, K.P., Butt, M.S., Truong, V.D. (2012). Glycemic index of sweet potato as affected by cooking methods. The Open Nutrition Journal, 6(1), 1-11.

5. AOAC (2005). Official Methods of Association of Official Analytical Chemists, 18th ed., Gaithersburg, USA.

6. AOCS (2009). Official Methods and Recommended Practices of American Oil Chemists' Society, 6th ed., Denver, USA.

7. Bergman, C., Gray-Scott, D., Chen, J.J., Meacham, S. (2009). What is next for the Dietary Reference Intakes for bone metabolism related nutrients beyond calcium, phosphorus, magnesium, vitamin D, and fluoride? Critical Reviews in Food Science and $\mathrm{Nu}$ trition, 49(2), 136-144.

8. Bvenura, C., Afolayan, A.J. (2014a). Maturity effects on mineral concentration and uptake in Solanum nigrum L. Acta Agriculturae Scandinavica, Section B - Soil and Plant Science, 64(8), 657-665.

9. Bvenura, C., Afolayan, A.J. (2014b). Mineral uptake in Solanum nigrum L. cultivated on fertilizer amended soils of the Eastern Cape, South Africa. Journal of Applied Botany and Food Quality, 87, 220-226.

10. Carvalho, F.M.C., Lima, V.C.O., Costa, I.S., Medeiros, A.F., Serquiz, A.C., Lima, M.C.J.S., Serquiz, R.P., Maciel, B.L.L., Uchôa, A.F., Santos, E.A., Morais, A.H.A. (2016). A trypsin inhibitor from tamarind reduces food intake and improves inflammatory status in rats with metabolic syndrome regardless of weight loss. Nutrients, 8(10), 544-558.

11. Clemente, M., Corigliano, M., Pariani, S., Sanchez-Lopez, E., Sander, V., Ramos-Duarte, V. (2019). Plant serine protease inhibitors: biotechnology application in agriculture and molecular farming. International Journal of Molecular Sciences, 20(6), $1345-1365$.

12. Dansi, A., Adjatin, A., Adoukonou-Sagbadja, H., Falade, V., Yedomonhan, H., Odou, D., Dossou, B. (2008). Traditional leafy vegetables and their use in the Benin Republic. Genetic Resources and Crop Evolution, 55(8), 1239-1256.

13. Das, S., Hussain, N., Gogoi, B., Buragohain, A.K., Bhattacharyaa, S.S. (2017). Vermicompost and farmyard manure improves food quality, antioxidant and antibacterial potential of Cajanus cajan (L. Mill sp.) leaves. Journal of the Science of Food and Agriculture, 97(3), 956-966.

14. Djibril Moussa, M.I., Alashi, A.M., Sossa-Vihotogbe, C.N.A., Akponikpe, P.B.I., Djenontin, A.J., Baco, M.N., Akissoé, N.H., Aluko, R.E. (2019a). Inhibition of renin-angiotensin system enzymes by leafy vegetables polyphenol extracts related to fertilizer micro-dosing and harvest time. Acta Horticulturae, 1238, 73-80.

15. Djibril Moussa, M.I, Alashi, A.M., Sossa-Vihotogbé, C.N.A., Akponikpè, P.B.I, Baco, N.M., Djènontin, A.J, Aluko, R.E., Akissoé, N.H. (2019b). Fertilizer micro-dosing and harvesting time of indigenous leafy vegetables affect in vitro antioxidant activities. Journal of Food Bioactives, 6, 118-130.

16. Fonge, B.A., Bechem, E.E., Awo, E.M. (2016). Fertilizer rate on growth, yield, and nutrient concentration of leafy vegetables. International Journal of Vegetable Science, 22 (3), 274-288.

17. Jedinak, A., Valachova, M., Maliar, T., Sturdik, E. (2010). Antiprotease activity of selected Slovak medicinal plants. Pharmazie, 65(2), 137-140.

18. Likpètè, D.D., Adjogboto, A., Akponikpe, P.B.I., Djenontin, A.J., Baco, M.N., Sossa-Vihotogbe, C.N.A., Agbossou, E.K. (2019). Water use efficiency of local amaranth as affected by timing and application methods of fertilizer micro-dosing. Acta Horticulturae, 1238, 45-54.

19. Nana, F.W., Hilou, A., Millogo, J.F., Nacoulma, O.G. (2012). Phytochemical composition, antioxidant and xanthine oxidase inhibitory activities of Amaranthus cruentus L. and Amaranthus hybridus L. extracts. Pharmaceuticals, 5(6), 613-628.

20. Patel, S.S., Zaveri, M.N. (2015). Trypsin and protein denaturation inhibitory activity of leaf and root of Justicia gendarussa. Asian Journal of Pharmaceutical Science and Technology, 5(4), 217-223.

21. Pesoti, A.R., Oliveira, B.M., Oliveira, A.C., Pompeu, D.G., Gonçalves, D.B., Marangoni, S., Silva, J.A., Granjeiro, P.A. (2015). Extraction, purification and characterization of inhibitor of trypsin from Chenopodium quinoa seeds. Food Science and Technology, 35(4), 588-597.

22. Sawka, M.N. (2005). Dietary Reference Intakes for Water, Potassium, Sodium, Chloride, and Sulfate. Washington, DC, USA, The National Academies Press.

23. Shahwar, D., Raza, M.A., Shafiq-Ur-Rehman, Abbasi, M.A., Atta-Ur-Rahman (2012). An investigation of phenolic compounds from plant sources as trypsin inhibitors. Natural Product Research, 26(12), 1087-1093.

24. Sossa-Vihotogbé, C.N.A., Anihouvi, B.V., Akissoe, H.N., Amadji, L.G., Hounhouigan, D.J. (2013). Effect of organic and mineral fertilization on proximate composition of three leafy vegetables harvested at different periods. International Journal of Biological and Chemical Sciences, 7(1), 271-286.

25. Souza, M.R.M., Pereira, P.R.G., Magalhães, I.P.B., Sediyama, M.A.N., Vidigal, S.M., Milagres, C.S.F., Baracat-Pereira, M.C. (2016). Mineral, protein and nitrate contents in leaves of Pereskia aculeata subjected to nitrogen fertilization. Pesquisa Agropecuária Tropical, 46(1), 43-50.

26. Tovihoudji, P.G., Akponikpè, P.B.I., Agbossou, E.K., Bertin, P., Bielders, C.L. (2017). Fertilizer microdosing enhances maize yields but may exacerbate nutrient mining in maize cropping systems in northern Benin. Field Crops Research, 213, 130-142.

27. Trumbo, P., Yates, A.A., Schlicker, S., Poos, M. (2001). Dietary reference intakes: vitamin A, vitamin $\mathrm{K}$, arsenic, boron, chro- 
mium, copper, iodine, iron, manganese, molybdenum, nickel, silicon, vanadium, and zinc. Journal of the American Dietetic Association, 101 (3), 294-301.

28. Vodouhè, S., Dovoedo, A., Anihouvi, V.B., Tossou, R.C. (2012) Influence du mode de cuisson sur la valeur nutritionnelle de Solanum macrocarpum, Amaranthus hybridus et Ocimum gratissimum, trois légumes-feuilles traditionnels acclimatés au Bénin.
International Journal of Biological and Chemical Sciences, 6(5), 1926-1937 (in French; English abstract).

29. Watts, D.L. (2010). HTMA mineral ratios. A brief discussion of their clinical importance. Trace Elements Newsletter, 21, 1-3.

Submitted: 19 December 2019. Revised: 12 February, 16 and 20 March 2020. Accepted: 25 March 2020. Published on-line: 17 April 2020. 